\title{
PROGRAM FOR KULTUR
}

Islands formandskab 2019

III) Nordisk Ministerråd

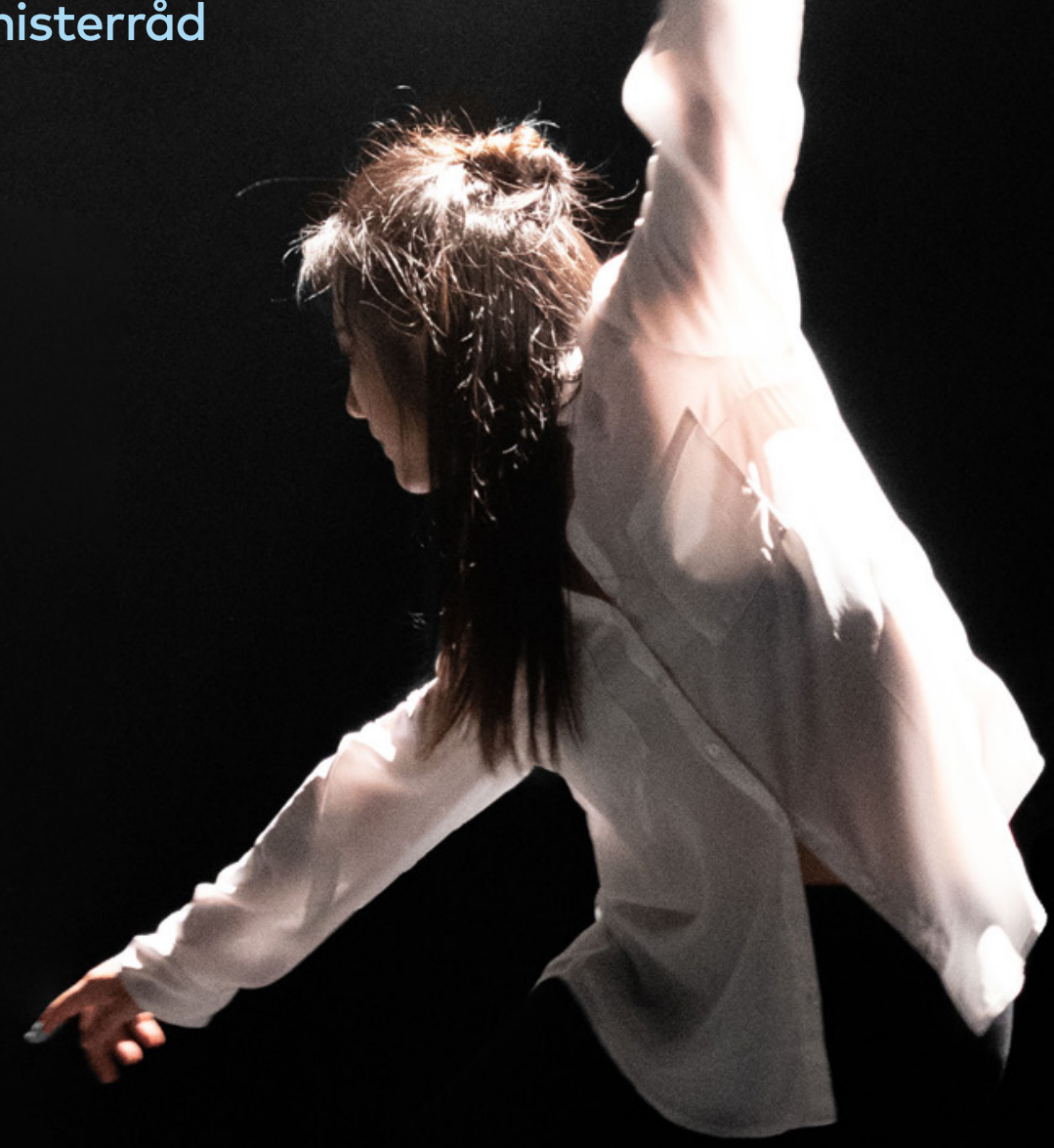




\section{PROGRAM FOR KULTUR}

ISLANDS FORMANDSKAB 2019 FOR NORDISK MINISTERRÅD

PolitikNord 2019:726

ISBN 978-92-893-6149-1 (PDF)

ISBN 978-92-893-6150-7 (EPUB)

http://dx.doi.org/10.6027/PN2019-726

(c) Nordisk Ministerråd 2019

Layout: Louise Jeppesen

Omslagsfoto: unsplash.com

\section{Det nordiske samarbejde}

Det nordiske samarbejde er en af verdens mest omfattende regionale samarbejdsformer. Samarbejdet omfatter Danmark, Finland, Island, Norge og Sverige samt Færøerne, Grønland og Åland.

Det nordiske samarbejde er både politisk, økonomisk og kulturelt forankret, og er en vigtig medspiller i det europæiske og internationale samarbejde. Det nordiske fællesskab arbejder for et stærkt Norden i et stærkt Europa.

Det nordiske samarbejde ønsker at styrke nordiske og regionale interesser og værdier i en global omverden. Fælles værdier landene imellem er med til at styrke Nordens position som en af verdens mest innovative og konkurrencedygtige regioner.

\section{Nordisk Ministerråd}

Nordens Hus

Ved Stranden 18

1061 København K

www.norden.org

Download og bestil nordiske publikationer: www.norden.org/nordpub 


\section{PROGRAM FOR KULTUR}

Islands formandskab 2019 for Nordisk Ministerråd

$\mathbb{1} \mid \mathrm{C}^{3}$

$4 \quad$ Indledning

5 Det overordnede Islandske formandskab for perioden 2019 - 2021

6 Platform GÁTT

8 Sektor specifikke aktiviteter 2019 


\section{INDLEDNING}

Overskriften for det islandske formandskab i 2019 er inspireret af Hávamál, den cirka tusind år gamle eddadigtning. Denne fælles kulturarv indeholder en dybsindig vejledning til et ærbart liv og et godt forhold mellem mennesker. Digtene i Hávamál fortæller os, at der altid findes en kort vej genvej - til en god ven. Således ligger der genveje mellem de nordiske lande.

Formandskabsprogrammet tager udgangspunkt i Nordisk Ministerråds tværsektorielle strategier om ligestilling, børn og unge, og bæredygtig udvikling. FN's verdensmål er en integreret del i hele formandskabsprogrammet.

Den teknologiske revolution har skabt vendelige muligheder. Denne udvikling opfordrer også til presserende udfordringer som store ændringer i kommunikation og sprogbrug, specielt hos børne og unge. Dette kræver en revurdering af nordisk sprogsamarbejde. Under det arbejde må der tages højde for de unges synspunkter. MR-U har hovedansvaret for sprogsamarbejdet men MR-K har sektoransvar.

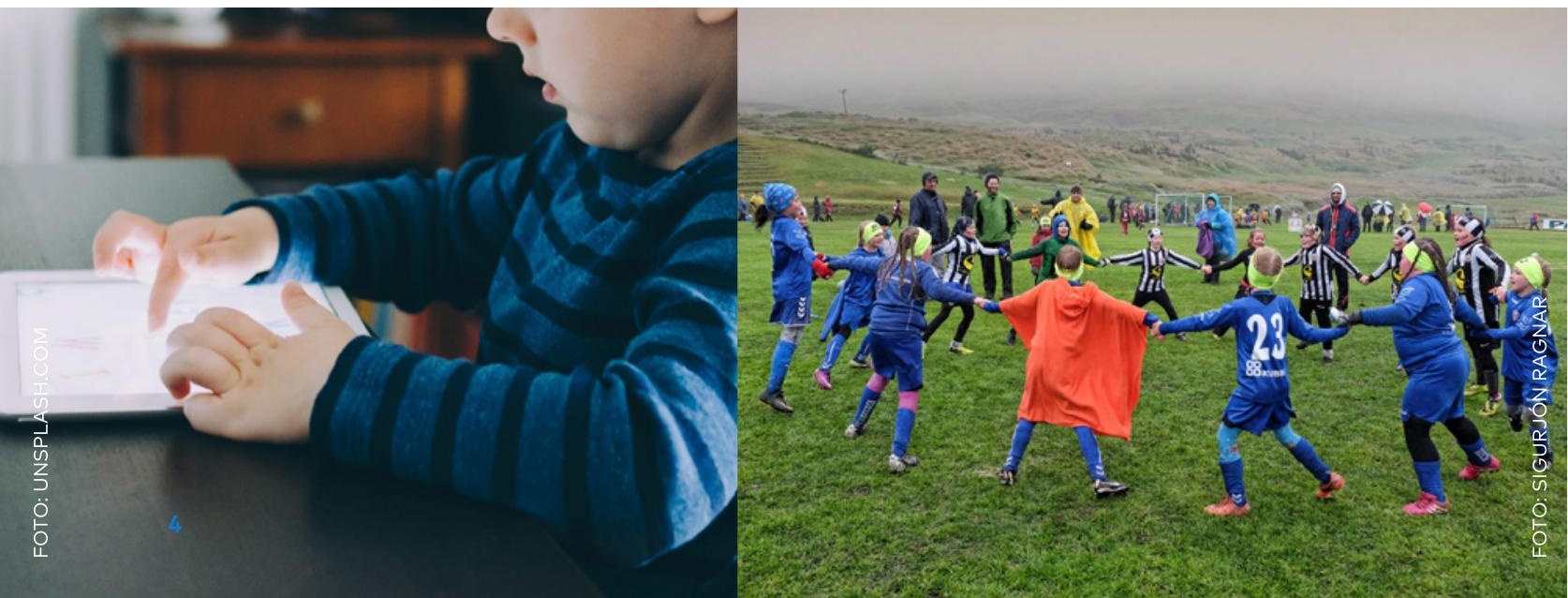




\section{DET OVERORDNEDE ISLANDSKE FORMANDSKAB FOR PERIODEN 2019 - 2021}

Programmet i sin helhed beskriver tre hovedprioriteringer:

UNGE MENNESKER I NORDEN, tager udgangspunkt i unges menneskers synspunkter. Vi vil gerne lytte til dem og lancerer projekter der fremmer uddannelse, kultur og sundhed med deres aktive deltagelse.

\section{BAEREDYGTIG TURISME I NORD,} fokuserer på fælles nordiske udfordringer der omhandler bæredygtig turisme; at skabe balance mellem vækst i antallet af gæster og beskyttelse af vores sårbare natur.

\section{HAVET - BLÅ VAEKST I NORD,} handler om de udfordringer og muligheder der havet og den blå bioøkonomi skaber i Norden. Havet forbinder de nordiske lande, samtidigt med at bæredygtig anvendelse af naturressourcer skaber arbejdspladser og øget værdi.
Hver hovedprioritering deles op i tre formandsskabsprojekter. Indenfor hovedprioriteringen Unge i Norden har Undervisnings-, forsknings- og kulturministeriet i Island ansvar for projektet Uddannelse for alle med vægt på demokrati, ligestilling, bæredygtighed og globalt medborgerskab 2019-2021 og Platform GÁTT som har som mål at etablere et nætverk mellem kunstfestivaler med fokus på at synliggøre unge profesionelle kunstnere i Norden og skabe et nordisk forum for deres kunst. Det tredje projekt indenfor Unge Mennesker i Norden er Barnets første tusind dage (EK-S).

$\rightarrow$ Link til programmet for Islands formandskab 2019 for Nordisk Ministerråd 


\title{
PLATFORM GÁTT
}

\author{
Netværk mellem kunstfestivaler med fokus på unge \\ profesionelle kunstnere i Norden og etabeling af \\ et nordisk forum for deres kunst 2019-2021
}

\section{INDLEDNING}

Projektets mål er at etablere et netværk mellem kunstfestivaler med fokus på at synliggøre unge profesionelle kunstnere i Norden og skabe et nordisk forum for deres kunst. Hurtige udviklinger på den internationale arena og stigningen $\mathrm{i}$ befolkningen fra andre kulturer i Norden kræver ændringer i det nordiske samarbejde. Det unge bruger metoder tvært på kunstarter og arbejder uden grænser. Kultur og kulturens bidrag til samfundet kan have en afgørende betydning for det interkulturelle Norden. Samarbejdsnetværk vil blive dannet mellem kunstnere fra hele Norden som kan byde på en fælles platform og et samarbejdsgrundlag for dialog og diskussioner, der fremmer den personlige såvel som den samfundsmæssige udvikling og bidrager dermed til et bæredygtigt samfund.

\section{ORGANISATION}

Projektet gennemføres i et samarbejde mellem tre højt profilerede multidisciplinære kunst festivaler (Reykjavík, Bergen, Helsinki) og to nordiske kulturinstioner (NAPA og NLH). De mødes i Platform GÁTT på forskellige steder i Norden for at fremhæve unge spirende og professionelle kunstnere fra regionen gennem en række arrangementer.

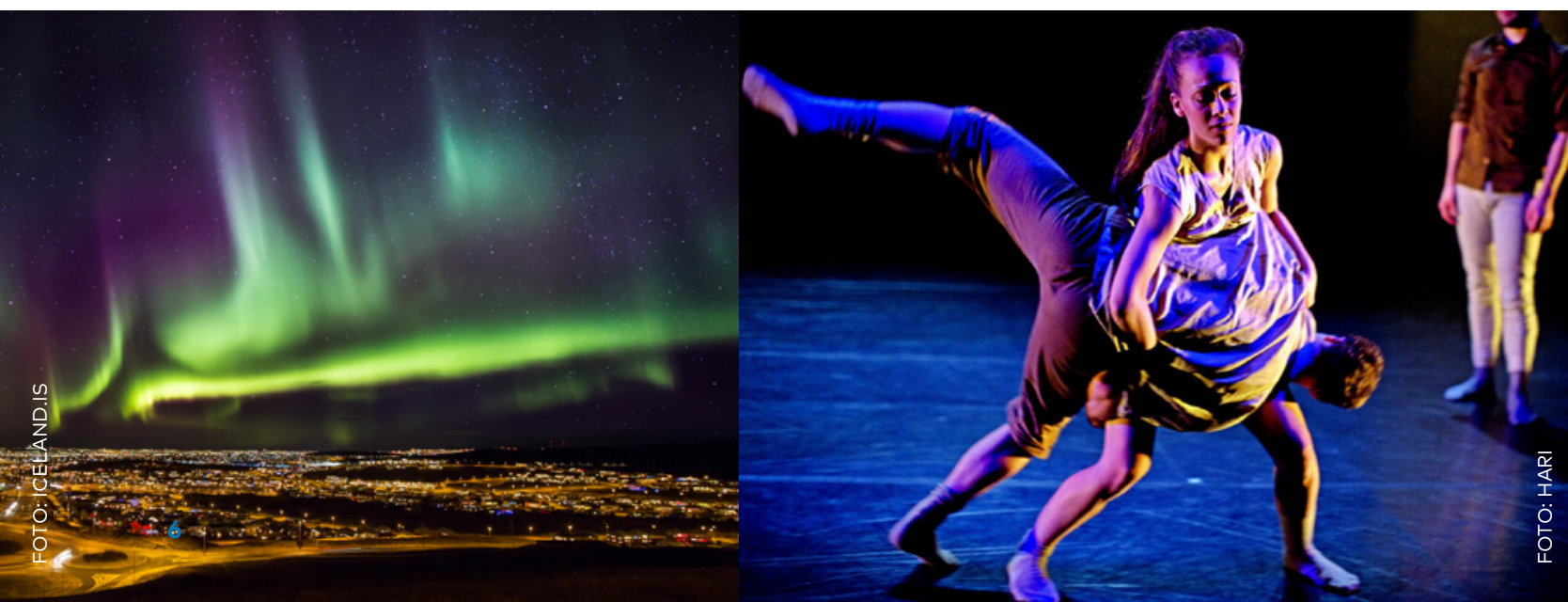




\section{PROJEKTDELE}

2019

Marts - april

Open call for deltagelse

Maj (24. -26.)

1. Arrangement: Festival i Bergen

Oktober

2. Arrangement: Festival i Nuuk

2020

Juni

3. Arrangement: Festival i Reykjavík

August

4. Arrangement: Festival i Helsinki

2021

5. Arrangement: Kulturfest i Torshavn

Maj/juni

Slutarrangement: Møde/konference i Reykjavík.

I forbindelse med ISPA (Interntional Society for

Performing Arts) konference i Harpa koncerthus.

\section{ANSVARLIG}

Undervisnings-, forsknings- og kulturministeriet i Island.

\section{PROJEKTFORVALTNING}

Listahátíð í Reykjavík (Reykjavík Kunst

Festival) bliver forvaltningsorgan og

har ansvaret for udførelsen af projektet

og koordinering af alle delprojekter.

Listahátío í Reykjavík ejes af den

islandske stat og Reykjavík kommune.

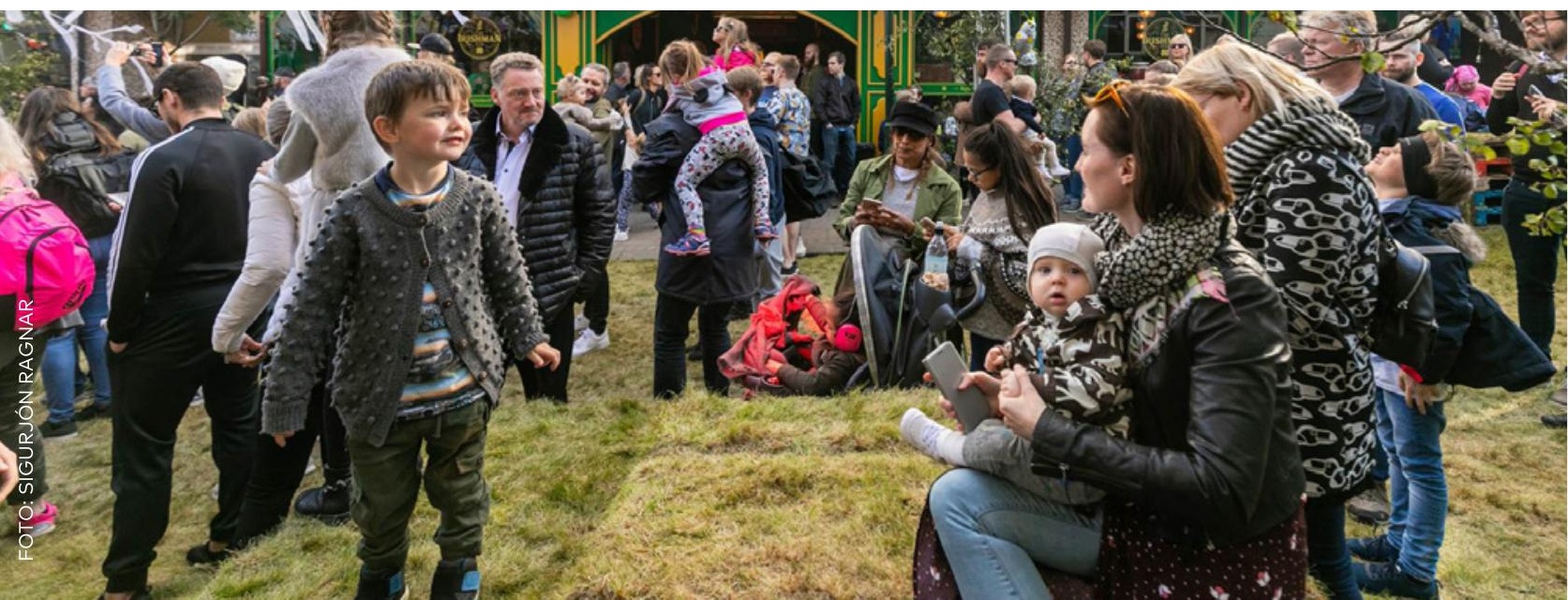




\section{SEKTOR SPECIFIKKE AKTIVITETER 2019}

The Weather Diaries: Vestnordisk design udstilling i de tre baltiske lande

Der udstilles arbejde af tolv modeskabere fra Island, Grønland og Færøerne. Med en række arrangementer - udstilling, konference og workshop er meningen at inspirere lokale baltiske designere og modeproducenter til at bidrage til en holdbar og socialt ansvarlig production, opmuntre til en bred dialog og ansvarlige konsumenter samt præsentere vestnordiske/nordiske værdier i modebranchen.

Tidspunkt: 1. januar 2019 - 31. januar 2020

\section{Arts Arctic Summit: Kultursamarbejde i det arktiske område - en konference i Rovaniemi}

Temaet Kultursamarbejde i det arktiske område blev først diskuteret under Norges formandskab i 2017 på en konference i Harstad. Finland inviterede til en ny konference i 2019 og Island har taget den ind i sit formandskab, ikke mindst i lyset af at Island overtager formandskabet i Arktisk råd i juni 2019. Målet med konferencen er bl.a. at finde løsninger på et curkumpolar samarbejde, specielt mellem Norden og andre medlemmer af Arktisk råd.

Tidspunkt: 3. - 5. juni 2019
Nordisk/International konference om verdensarvskonventionen fra 1972 I samarbejde med UNESCO bliver der efteråret 2019 arrangeret en konference med fokus på emnet "good governance" og bedre løsninger på forvaltning af eksisterende verdensarv. Fokus bliver også på transnationalt samarbejde og muligheder i at etablere verdensarvområder med god integritet.

Tidspunkt: 24. - 25. oktober 2019

Nordiske kunstnere med flerkulturel baggrund

Målet med projektet er at etablere et kunstnerisk netværk og erfaringsgruppe for kunstere med flerkulturel baggrund. Det er et delprojekt inden Norges treårige formandskabsprogram fra 2017 om inkludering og kulturens rolle i intergrering af nye borgere. Målet er at etablere kunstnerisk netværk og erfaringsgruppe. Det sker igennem workshop i København og kunstnertræf på Island for og med nye og etablerede kunstnere med indvandrerbaggrund. Island har i gennem sit formandskab sikret deltagelse af kunstrere fra henholdsvis Færøerne og Grønland.

Tidspunkt: 29. - 30. april $2019 \mathrm{i}$

København, 9. - 11. september 2019

i Island 
Nordisk netverksseminarium for at styrke uafhængig kvalitetsjournalistik Seminaret deles op i to dele. Den første del handler om kvalitetsjournalistik og netværksdannelse og er en opfølgning på Sveriges formandskabsprojekt 2018 om samme tema og dets rekommendationer. Den anden del handler om Medieog informationkundskab, "best practice" i Norden om hvordan man formidler information til voksne om disinformation og falske nyheder med henvisning til demokratispørgsmål og hvordan dette kan påvirke demokratiet i samfundet.

Tidspunkt: 18. oktober 2019
Nordisk konference: De islandske sagaer i en ny udgave på dansk/norsk/svensk og islandsk. - Og hvad så?

Under Islands sidste nordiske formandsskab i 2014 udkom de islandske sagaer i en ny oversættelse på dansk/norsk/ svensk og i 2018 blev de publiceret på moderne islandsk i anledning af 100 års jubilæeet for Islands suverænitet. Nu er spørgsmålet hvordan kan vi formidle denne fælles kulturarv til nye generationer. Hvad har vi lært af det store oversættelsesprojekt som varede i næsten 10 år? Der arrangeres en nordisk konference med bl.a. disse temaer $\mathrm{i}$ fokus.

Tidspunkt: 6. - 7. september 2019.
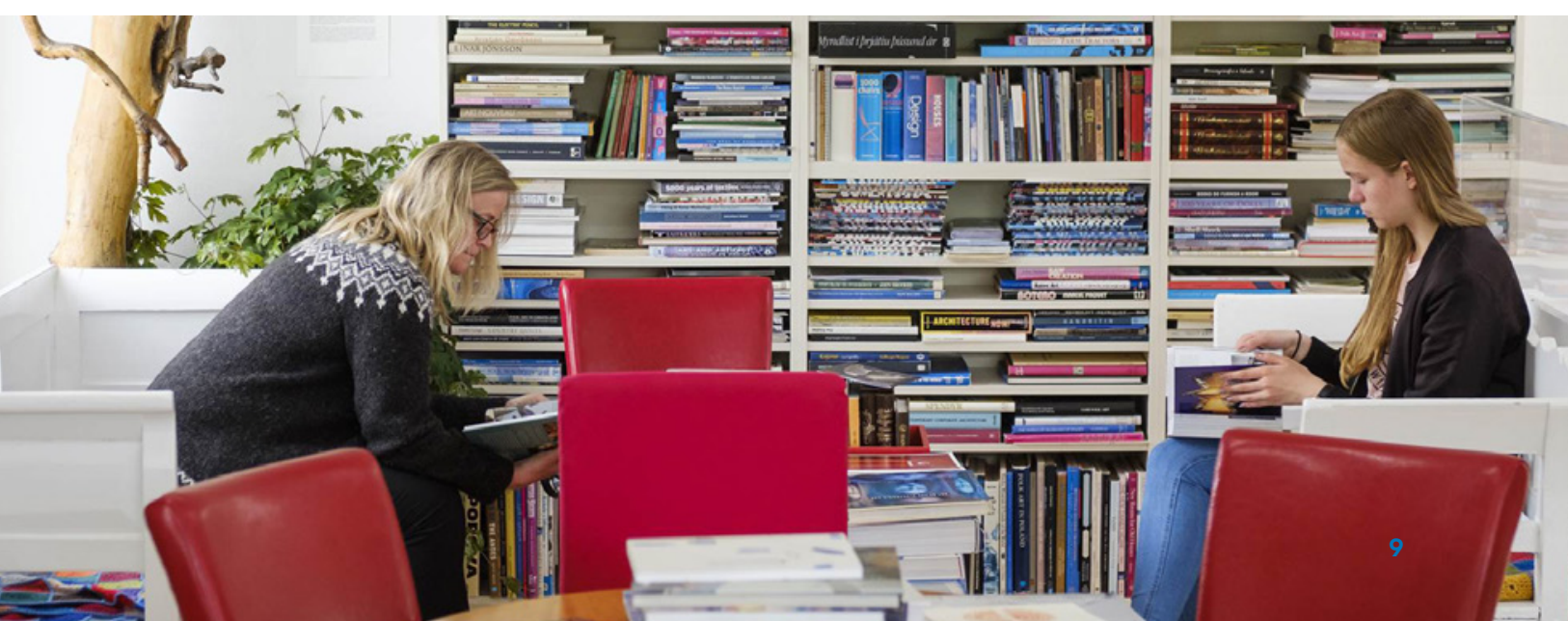


\section{Nordisk Ministerråd}

Nordens Hus

Ved Stranden 18

1061 København

www.norden.org 